\section{Bender Elected President of IAA Board}

At the IAA Board's annual March meeting, held this year at the National 4-H Center in Chevy Chase, Maryland, Jim Bender, a commercial scale organic farmer from Weeping Water, Nebraska, was elected President of the IAA. Michael Heller, Manager of the Chesapeake Bay Foundation's Claggett Farm in Maryland, was named Vice President. Dr. Katherine Clancy of Syracuse University and The Honorable Robert $O$. Blake of Washington, DC, were reelected Treasurer and Secretary, respectively.

The Board heard an interim report from Robert Gray, President of Resource Management Consultants, Inc., Washington, DC, on interviews he is conducting with agricultural leaders. Gray's work is part of IAA's strategic planning process, which is being carried out under a planning grant from The Ford Foundation.

The Institute's 1993 conference will address needed policy reforms, with a special focus on ways to "build bridges" of understanding and dialogue across major U.S. agricultural regions.

\section{IAA Conference Examines Farming-Rural Community Ties}

The many critical links between alternative agriculture and rural communities-and their constituencieswere analyzed at the IAA's 9th Annual Conference on March 2-3, entitled "Alternative Farming Systems and Rural Communities--Exploring the Connections." Welcoming the 200 registrants from 36 states and 107 organizations, IAA Executive Director Garth Youngberg said that the adoption of sustainable farming systems "could begin to restore vibrancy to rural areas" hardhit by the increasing dominance of commercial and contract farming in the 1970 s and 1980 s.

In the opening speech, Dr. Sara Ebenreck of St. Mary's College noted that humans are a "communitycreating species," and that "our vision of who we really are, as members of multiple communities, is deepened and made ever more alive when we seek to make the connections between all the communities we belong to." A healthy local community must have a sound economy, positive social indicators, interaction with outside groups, and a "sense of the life of the mind and spirit," she concluded.

North Dakota farmer Dr. Fred Kirschenmann spoke of local sustainable agriculture networks as new rural communities which could invent new answers to the question, "What can farming and rural communities do for each other?" Because "sustainable agriculture dances with nature," he said, it "may reconnect us with nature in a manner that could make the evolution of ecological and social standards for rural communities inevitable."

At the center of the debate about the health of rural communities and American farms is sustainable agriculture, according to Marty Strange of the Center for Rural Affairs. He proposed that "alternative agriculture as a movement is dying--a victim of its own success-but will be reborn." The most important future issue for sustainable agriculture, he said, is not how big can a sustainable farm be, but how small does a farm have to be to be sustainable?

Several other speakers analyzed sustainable agriculture's past and present lessons and what they might mean for the well-being of rural communities. Sustainable agriculture needs committed people and public policies to ensure reasonable profits, according to Mark Ritchie of the Institute for Agriculture and Trade Policy. Also required is ac- tive dialogue between farmers, farmers' organizations, researchers, and policymakers in order to develop policies that will address the nation's food, farm, social, and environmental needs, according to Kurt Rohland, a dairy farmer who heads the National Family Farm Coalition. Rudi Buntzel, who works with sustainable agriculture farmers in Germany, offered an international example of organic farmers so successful that the agricultural collectives have shifted to organic farming to compete in the now profitable market of organic produce.

Five work groups that concluded the conference developed strategies to restore or create healthy connections between agriculture and rural communities, with a consensus of participants agreeing that there is a need to mobilize scientists, young people, and other newcomers to the sustainable agriculture movement. All also agreed that survivability is the first requirement for sustainability--and that the people who care about sustainable agriculture and rural communities have much in common, much to share, and much to gain by working together for that survivability.

\section{Dr. Warren Sahs Receives Traillblazer Award}

Dr. Warren Sahs, Professor Emeritus at the University of Nebraska and a former IAA President, has received a 1991 "Safe Food Trailblazer" award from the Center for Science in the Public Interest. Dr. Sahs was honored for his outstanding achievement, "leadership, and courage in becoming the first mainstream agricultural scientist to initiate long-term research trials comparing conventional and organic production systems." 